Структурний компонент моделі «Зміст підготовки майбутніх учителів» складається із двох блоків: загальний блок, до якого відносять зміст загальноосвітніх навчальних дисциплін, передбачених навчальним планом вищого навчального закладу; методичний блок, до якого віднесено зміст навчальних дисциплін, зокрема спецкурс «Використання IКТ на уроках математики», передбачений навчальним планом.

Структурний компонент моделі «Форми, методи й засоби підготовки» містить набір форм, методів і засобів підготовки майбутніх учителів математики до використання IКТ у процесі викладання математики в 5-6 класах, які використовуються під час навчального процесу у вищому навчальному закладі. До них ми відносимо: аудиторні заняття (лекції, семінари, практичні заняття тощо); самостійну роботу студентів; педагогічну практику; курсові роботи; навчально-дослідницькі роботи тощо.

Також ми виокремлюємо спецкурс «Використання IКТ у шкільному курсі математики», який спрямований на підготовку майбутніх учителів до використання IКТ у навчальновиховному процесі.

Результатом упровадження моделі $є$ готовність майбутніх учителів до використання IКТ на уроках математики в 5-6 класах.

Усі зазначені компоненти складають систему підготовки майбутніх учителів до використання IКТ на уроках математики в 5-6 класах.

У процесі навчання майбутніх учителів використанню інформаційно-комунікаційних технологій навчання в педагогічному вищому навчальному закладі постає мета створення цілісної системи знань, умінь, навичок із використання інформаційно-комунікаційних технологій та набуття досвіду самостійної роботи з відповідними засобами, що за умов мотивації навчання та прагнення до впровадження нового забезпечить формування готовності майбутніх учителів математики до впровадження засобів інформаційно-комунікаційних технологій у навчально-виховний процес загальноосвітньої школи. Подальшого розроблення вимагає підготовка студентів до використання IКТ у старших, зокрема в 10-11 класах.

\title{
Література
}

1. Апатова Н. П. Інформаційні технології в навчанні математики / Н. П. Апатова // Сучасні інформаційні технології в навчальному процесі. - К. : НПУ, 1997. - С. 39. 2. Володько В. М. Основні компоненти загальнопедагогічної підготовки майбутнього вчителя / В. М. Володько // Проблеми сучасної педагогічної освіти: [зб. ст.]. - К. : КДГІ, 2001. - Вип. 3. - С. 25-32. 3. Дяченко С. І. Комп'ютерна техніка на уроках математики / С. І. Дяченко // Відкритий урок. - 2009. - № 6. - С. 7679. 4. Забранський В. Я. Організаційні засади самостійної роботи майбутніх учителів математики у процесі методичної підготовки / В. Я. Забранський // Дидактика математики: проблеми і дослідження: [міжнародний зб. наук. робіт]. - Вип. 25. - Донецьк: Фірма ТЕАН, 2006. - С. 81-87. 5. Шумигай С. М. Використання комп’ютерних технологій на уроках математики / С. М. Шумигай // Комп’ютер в школі та сім’ї. - 2010. - № 7. - С. 18-21.

УДК 378:004+78

Лариса Варнавська

\section{ФОРМУВАННЯ ГОТОВНОСТІ СТУДЕНТІВ ДО ВИКОРИСТАННЯ КОМП'ЮТЕРНИХ ТЕХНОЛОГІЙ НА УРОКАХ МУЗИКИ}

Варнавська Л. І. Формування готовності студентів до використання комп’ютерних технологій на уроках музики.

У статті розглянуто питання професійної підготовки студентів, використання ними комп'ютерних технологій на уроках музики та формування готовності до такого виду діяльності; конкретизовано поняття «готовність до використання комп'ютерних технологій на уроках музики».

Ключові слова: готовність студентів, комп'ютерні технології, урок музики.

Варнавская Л. И. Формирование готовности студентов к использованию компьютерных технологий на уроках музыки.

В статье рассмотрен вопрос профессиональной подготовки студентов, использования ими компьютерных технологий на уроках музыки и формирование готовности к такому виду деятельности; конкретизировано понятие «готовность к использованию компьютерных технологий на уроках музыки».

Ключевые слова: готовность студентов, компьютерные технологии, урок музыки. 
Varnavskaya L. I. Formation of Students' Readiness for Using Computer Technologies at Music Lessons.

The article analyses the issues of professional training, computer technologies usage at music lessons and the formation of students' readiness to this type of activity; the meaning of «readiness for using the computer technologies at music lessons is defined concretely».

Key words: students' readiness, computer technologies, music lesson.

XXI ст. висуває нові вимоги до освіти, надає нові можливості для освітньої діяльності. Передовсім це пов'язано із сучасними інформаційними технологіями, комп'ютерною технікою, що використовується як засіб набуття комп'ютерної грамотності, вивчення предметів, шлях до знань і досвіду людства.

Підписання Україною Болонської конвенції щодо створення загальноєвропейського простору вищої освіти у межах інтеграційних процесів вимагає від вищих навчальних закладів кардинальних змін у підготовці педагогічних кадрів, спроможних творчо працювати в умовах сучасної освіти.

Комп’ютерні технології $є$ потужним інструментом для отримання найрізноманітнішої інформації, ефективним засобом підвищення інтересу до навчання, а також мотивації, науковості, наочності тощо. Комп'ютерні засоби навчання відкривають нові технологічні можливості для педагогіки мистецтва, поліхудожнього виховання студентів, мають переваги порівняно з традиційним навчанням. Застосування таких технологій дозволить змінити весь процес навчання.

У науковій літературі висвітлено багато поглядів на проблему готовності. Дослідження 3 проблеми формування готовності та професійної готовності здійснювали О. Абдуліна, Б. Ананьєв, Л. Виготський, К. Дурай-Новакова, В. Ільїн, О. Леонтьєв, С. Рубінштейн, В. Серіков, В. Сластьонін і багато інших.

Метою статті є висвітлення питань використання комп'ютерних технологій на уроках музики та формування готовності студентів до цього виду діяльності.

Одним із важливих сучасних напрямків розвитку професійно-педагогічної підготовки $\epsilon$ оновлення іï пріоритетів, мети, змісту, форм і методів, формування готовності майбутнього вчителя до швидких соціальних та освітніх змін у суспільстві. Реалізація цих завдань значною мірою залежить від здатності майбутніх учителів використовувати сучасні освітні технології, $\mathrm{i}$ в передовсім - комп'ютерні. Під час підготовки педагогічних кадрів до сучасного рівня професійної діяльності необхідно ознайомлювати їх із загальними особливостями педагогічної діяльності, сучасними вимогами до навчально-виховного процесу школи, яка постійно модернізується й розвивається.

Питання підготовки вчителя музики досліджували О. Апраксина, А. Арчажникова, Б. Асаф’єв, Н. Ветлугіна, Г. Падалка, О. Ростовський, О. Щолокова та ін.

Психолого-педагогічні аспекти використання нових інформаційних технологій у навчальному процесі розглядаються у працях М. Жалдака, В. Зінченка, Ю. Машбиця та ін. Питання удосконалення навчальних технологій за допомогою комп'ютера відображено в роботах І. Зязюна, Н. Волкової, І. Манькусь, М. Лебедєвої, І. Теплицького, Б. Ломова, О. Тихомирова та ін.

Проте, численні спроби перегляду професійно-педагогічної підготовки вчителів музики не розв'язують принципових суперечностей між: інтенсивною технологізацією навчального процесу, оснащенням шкіл сучасними комп’ютерними засобами та недостатністю готовності майбутнього вчителя музики до використання комп'ютерних технологій.

Успіх реалізації освітянських завдань у галузі музичної педагогіки визначається впровадженням у практику музичного навчання новітніх технологій і використанням нових підходів до його організації і змісту.

Засоби комп'ютерних технологій не можуть бути введеними в технології навчання як заміна традиційних засобів навчання, але вони здатні чинити суттєвий вплив на технологічний процес, який входить до структури педагогічної технології, зокрема на: організацію навчального процесу; методи і форми навчальної діяльності; методи і форми роботи викладача; діяльність викладача щодо управління процесом засвоєння знань; створити об'єктивні можливості для розроблення принципово нових технологій, які б відповідали цілям освіти. 
Свій підхід до застосування комп'ютерних технологій у музично-педагогічній освіті запропонували В. Луценко, В. Янкул, які розглядають це питання як систему прийомів, що забезпечують реалізацію мети і завдань педагогічної діяльності.

В. Козлін [3] пропонує використовувати комп'ютерні засоби навчання на уроках музики для розвитку почуття ритму, для чого було розроблено й реалізовано програму Music Rhythm як технічний засіб навчання.

Т. Затяміна [2] визнає, що комп'ютерні технології можуть стати дієвим засобом у музичній освіті, якщо вчитель правильно бачить мету, яка визначає результат як його діяльності, так і діяльності учнів, для чого виокремлюються як технологічні, так і методичні аспекти засвоєння комп'ютерних технологій.

Т. Рейзенкінд [4], розкриваючи роль комп'ютерних технологій у професійній підготовці вчителя музики, наголошує на тому, що застосування комп'ютерів у процесі навчання дисциплін естетично-художнього циклу є недостатнім, не визначено можливості застосування комп'ютерних підручників та посібників, завдань на тренінг інтелекту, вправ із формування готовності студентів до творчої діяльності.

Використання комп'ютера як інформаційного, навчального та контролюючого технічного засобу сприяє вдосконаленню традиційних методик проведення уроків музики.

Урок музичного мистецтва в загальноосвітньому навчальному закладі, який все частіше замінюе урок музики, спрямований на пізнання навколишнього світу засобами музичного мистецтва та розуміння учнями зв'язків музики з іншими видами мистецтва, природним і культурним середовищем життєдіяльності людини.

Одними 3 основних його завдань $є$ формування уявлень про сутність, види та жанри музичного мистецтва, особливості його інтонаційно-образної мови, засвоєння основних музичних понять і термінології; формування здатності використовувати набуті музичні знання та вміння; формування здатності сприймати та інтерпретувати музичні твори; розвиток загальних і музичних здібностей, творчого потенціалу особистості; збагачення емоційноестетичного досвіду, розвиток універсальних якостей творчої особистості; виховання музичних інтересів, смаку і потреб.

Саме на розв'язання цих завдань спрямовані уроки музики та музичного мистецтва із застосуванням комп'ютерних технологій. Кожен із таких уроків $є$ сукупністю малюнків, світлин, анімацій, відеофрагментів, текстових пояснень, звукового супроводу, зразкового виконання музичних творів, виконання пісень у режимі караоке, тестових запитань тощо. Найважливішим складником процесу навчання є не комп'ютери, а вчителі, озброєні методикою застосування комп'ютерних технологій, що підтверджують самі педагоги, наголошуючи, що сучасному вчителю для ефективного застосування комп'ютерних технологій на уроках потрібна не лише теоретична, а насамперед практична підготовка.

Формування готовності до використання комп'ютерних технологій на уроках музики студентами музично-педагогічного факультету - новий етап у професійній підготовці майбутнього учителя музики. Під час музично-педагогічної підготовки цьому питанню, на нашу думку, приділяється недостатньо уваги: відсутні науково-методичні розробки та підручники 3 використання комп’ютерних технологій в музично-педагогічній освіті, досить слабка матеріально-технічна база вищих навчальних закладів.

Аналіз психолого-педагогічних досліджень показав, що переважно погляди у витлумаченні поняття готовності взаємодоповнюють один одного. Водночас науковці доводять складність досліджуваного феномену й наполягають на тому, що готовність сучасного вчителя до професійної педагогічної діяльності $€$ складним багатогранним явищем й охоплює такі характеристики, як: достатній рівень оволодіння теоретичними знаннями і практичними вміннями та навичками; настанова й мотиви, спрямовані на успішне виконання професійної діяльності; позитивний настрій та здатність до продуктивної реалізації набутих знань у подальшій професійній діяльності.

Якщо розглядати готовність до педагогічної діяльності як явище, яке $є$ предметом вивчення багатьох педагогів і психологів, то можемо констатувати, що одні акцентують увагу на виявленні чинників, умов та засобів, що надають змогу керувати становленням і розвитком готовності, а інші - орієнтуються на встановлення характеру взаємозв'язків і залежностей між станом готовності та ефективністю діяльності. 
Комп'ютерна готовність, на думку М. Фіцули [5], передбачає ознайомлення з основними галузями застосування комп'ютерів, їх значенням у розвитку суспільства; поняття про алгоритми й алгоритмічну мову; уміння будувати алгоритми для розв'язання завдань; уміння користуватися комп'ютерними редакторами; уміння складати програми.

М. Жалдак [1] зазначає, що особливого значення у використанні інформаційнокомп'ютерних технологій у навчальному процесі набуває чинності розвиток неформалізованих, творчих компонентів мислення: реалізація проблемної ситуації чи постановка задачі; самостійне вироблення критеріїв добору потрібних операцій, що зумовлюють розв'язок; генерація гіпотез у процесі пошуку основної ідеї розв'язку (наукова технічна фантазія); матеріальна інтерпретація формального розв'язку тощо.

У сучасному суспільстві, коли викладач повинен добре орієнтуватися в новітніх педагогічних технологіях, комп'ютерному середовищі, майбутньому вчителю музики необхідно бути готовим володіти засобами комп'ютерних технологій для того, щоб навчити учнів використовувати комп'ютерні технології з навчальною метою, розвинути в них потребу у творчому використанні засобів комп'ютерних технологій у музиці для подальшого розвитку інтелекту, музичних здібностей, музичного смаку.

Отже, можна говорити про те, що готовність студентів до використання комп'ютерних технологій на уроках музики залежить від рівня їх психолого-педагогічної й теоретичної підготовки, уміння реалізовувати на практиці набуті теоретичні знання, оволодіння i правильного використовування засобів комп'ютерних технологій у музиці, знань основ музичної грамоти та музикування, творчого використання набутих знань під час проходження педагогічної практики та в подальшій професійній діяльності.

Узагальнюючи вищесказане, можемо зробити висновок, що готовність до використання комп'ютерних технологій - це складне особистісне утворення, основою якого є мотиваційнотворча сфера особистості, яке містить: сукупність психічних особливостей, що становлять основу настанови на використання комп'ютерних технологій; певний багатофункціональний рівень набутих знань під час навчання у вищому навчальному закладі та спроможність до творчого використання їх у майбутньому.

Формування готовності студентів до використання сучасних комп'ютерних технологій у музично-освітянському процесі - важлива проблема. Якщо використовувати виключно традиційні методи підготовки студентів, то вони не зможуть оволодіти всією сукупністю необхідних знань. Як зазначає Г. Ципін, комп’ютерні технології є одним із найоптимальніших шляхів поповнення багажу знань музиканта-педагога, розширення його художньоінтелектуальних обріїв, професійної ерудиції, а вміло використані сучасні технічні засоби дозволяють адаптувати музичний матеріал до особистісних вимог тих, хто навчається [6].

Формування готовності до використання комп'ютерних технологій вимагає створення системи педагогічних умов, які можуть забезпечити високий рівень підготовки майбутнього вчителя музики. Необхідними педагогічними умовами вдосконалення процесу підготовки майбутніх учителів музики є: наявність позитивної мотивації та потреби у використанні сучасних педагогічних технологій, зокрема комп'ютерних; реалізація міжпредметних знань, умінь та навичок, набутих за роки навчання у вищому навчальному закладі; методичне та матеріально-технічне забезпечення процесу формування окресленої готовності.

За останній час нами було розроблено та впроваджено в навчальний процес систему дисциплін: «Комп’ютерні технології в мистецько-педагогічній освіті», «Використання комп’ютерних музичних програм в шкільному пісенному репертуарі», «Використання комп'ютерних технологій на уроках музики», «Прийоми використання синтезатора в аранжуванні музичних творів», що сприяло формуванню досліджуваної готовності студентів; розроблено навчально-методичний комплекс до програми дисципліни «Використання комп'ютерних технологій на уроках музики», що стало теоретичним та практичним підгрунтям для формування готовності студентів до використання комп'ютерних технологій на уроках музики.

Комп'ютерні технології можуть стати надзвичайно ефективним засобом оптимізації музично-педагогічної освіти, якщо майбутній учитель чітко усвідомить мету, що визначає результат як його діяльності, так і діяльності учнів; підвищення вимог до якості професійної підготовки майбутніх учителів зумовлює необхідність пошуку шляхів, за наявності яких формується готовність студентів до використання комп'ютерних технологій на уроках музики. 


\section{Література}

1. Жалдак М. I. Педагогічний потенціал комп'ютерно-орієнтованих систем навчання математики / М. І. Жалдак // Комп'ютерно-орієнтовані системи навчання: зб. наук. пр. - № 7. - К.: НПУ ім. М.П.Драгоманова, 2003. - С. 3-15. 2. Затямина Т. Компьютерные технологии на уроке музыки / Т. Затямина // Искусство в школе. - 2006. - № 5. - С. 41-43. 3. Козлін В. Й. Використання комп'ютера в процесі формування почуття ритму / В. Й. Козлін // Комп’ютер у школі та сім’ї. 2001. - № 5. - С. 27-29. 4. Рейзенкінд Т. Комп’ютерне навчання в професійній підготовці вчителя музики / Т. Й. Рейзенкінд // Рідна школа. - 2003. - № 2. - С. 56-58. 5. Фіцула М. М. Педагогіка вищої школи: [навч. посіб.] / Михайло Михайлович Фіцула. - К. : Академвидав, 2006. - 352 с. 6. Цыпин Г. М. Принципы развивающего обучения в музыке / Психология музыкальной деятельности: Теория и практика / Григорий Михайлович Цыпин: [учеб. пособ. для студ. муз. фак. высш. пед. учеб. заведений] / под ред. Г. М. Цыпина. - М. : Академия, 2003. - 368 с.

УДК 371.332 .001 .89

Ірина Доценко

\section{ЗМІСТ І СТРУКТУРА НАУКОВО-ДОСЛІДНОЇ РОБОТИ СТУДЕНТІВ}

Доценко І. О. Зміст і структура науково-дослідної роботи студентів.

У статті на основі вивчення архівних матеріалів та інших джерел проаналізовано зміст і види науково-дослідної роботи студентів вищих навчальних закладів України у другій половині XX ст. та в сучасних умовах; визначено структуру науково-дослідної діяльності студентів, яка забезпечує ефективність навчального процесу та сприяє виявленню здібних студентів.

Ключові слова: науково-дослідна робота, структура науково-дослідної роботи, види науково-дослідної роботи, студент-дослідник.

Доценко И. О. Содержание и структура научно-исследовательской работы студентов.

В статье на основе изучения архивных материалов и других источников проанализированы содержание и виды научно-исследовательской работы студентов высших учебных заведений Украины во второй половине XX ст. и в современных условиях; определена структура научноисследовательской деятельности студентов, которая обеспечивает эффективность учебного процесса и способствует выявлению способных студентов.

Ключевые слова: научно-исследовательская работа, структура научно-исследовательской работы, виды научно-исследовательской работы, студент-исследователь.

Docenko I. O. Maintenance and structure of research work of students.

In the article on the basis of study of the archived materials and other sources maintenance and types of research work of students of higher educational establishments of Ukraine is analysed in the second half of XX centuries and in modern terms; the structure of research activity of students, which provides the effective type of educational process and instrumental in the exposure of capable students, is analysed.

Key words: research work, structure of research work, types of research work, student-researcher.

Творча праця фахівця незалежно від виду та характеру його роботи - це вимога часу. Фахівець повинен не тільки вміти виконувати все, що робили до нього інші, але й те, що ніхто до нього не робив. Тому необхідність залучення студентів до науково-дослідної роботи і набуття ними визначених навичок дослідника - вимога, яка висувається до кожного студента. Процес формування майбутнього фахівця стає більш ефективним, якщо студент перебуває в статусі дослідника. Цілеспрямована, педагогічно обгрунтована, організована робота студента може і повинна розглядатися як ефективний вид навчального процесу.

Мета статті - проаналізувати зміст та види науково-дослідної роботи студентів вищих навчальних закладів, структуру науково-дослідницької діяльності студентів, яка забезпечує ефективність навчального процесу та сприяє виявленню здібних студентів.

Сучасний етап розвитку вищої освіти характеризується пошуком нових шляхів співробітництва викладачів і студентів, у процесі яких відбувається формування ініціативи, самостійності та творчості останніх, залучення їх до дослідницько-пошукової навчальної 